\title{
Rhetorics and mechanics of player safety in the Nordic-American larp discourse
}

\author{
Michat Mochocki \\ Kazimierz Wielki University in Bydgoszcz \\ michal.mochocki@gmail.com | ORCID: 0000-0001-5679-9219
}

\begin{abstract}
This paper investigates the evolution of larp safety in the NordicAmerican larp community in the last decade, tracing the correlation between safety rhetorics (opinions, arguments, and policies) and mechanics (explicit rules regulating player interactions). It appears that up to around 2010 there was a general acceptance of risk, with a significant share of responsibility for risk identification and harm prevention put on the player. This correlates with mechanics such as safety words, which expected players in distress to actively signal their discomfort. Safety measures expected from the organisers consisted mainly in providing safe off-game spaces, emotional support, and intervention whenever something harmful happened. Around 2014 the safety debate put a larger share of responsibility on players initiating potentially troubling interactions. This correlates with the ' $0 \mathrm{~K}$ check' mechanics which requires communication between the initiator and the target of such interactions. Around 2016 the safety debate moved to the position in which it requires organisers and participants to do their best to prevent harm from ever happening. This finds its expression in the rapidly expanding toolkit of mechanics of consent and calibration, which clearly put responsibility for overstepping someone's boundaries on the one who oversteps. To simplify, the first approach obliged players and organisers to taking care of those who signalled they needed it. The second approach required caution and care in testing someone's boundaries. The last one states that boundaries are to be carefully identified and respected - not tested.
\end{abstract}

Keywords: larp, role-playing, safety, game mechanics 



\section{Introduction}

This paper investigates the evolution of larp safety in the last decade, tracing the correlation between safety rhetorics (opinions, arguments, and policies) and mechanics (explicit rules regulating player interactions). I will focus on the Nordic-American larp discourse, which originated in the English-speaking Knutepunkt/Solmukohta larp conferences (in 1997) in the Nordic countries (see Knutepunkt, 2019), and has since become a global phenomenon. Not to be generalised to all Nordic and American larp discourse, the paper is centred on the theory and design of the Nordic Larp movement, most notably the Knutepunkt/Solmukohta books, whose contributors have also produced the bulk of academic larp studies in English. I call it 'Nordic-American' discourse due to the increasing influence of Americans as scholars, larpwrights and community leaders, with extensive Nordic-American collaboration in larp design, theorycrafting and policymaking. American voices are particularly strong in the debate on larp safety (e.g. Atwater, Bowman, Brown).

Given the word limit of this paper, it is impossible for me to explain what larp (live-action role-playing) is to readers who are not familiar with it. I can only kindly ask them to refer to Harviainen et al. (2018), or perhaps Wikipedia (Live action role-playing game, 2019). Below, I will assume that readers already have an understanding of this form of roleplay.

There are three main areas of larp safety/risk: physical health, intimate role-play, and psychological trauma from triggering content and/or too stressful interactions. All of them can be addressed with dedicated larp mechanics: pre-defined rules of behaviour and communication codes. Some safety-related mechanics are representational: they represent ingame actions and events symbolically - not via full-body live action. They most commonly include combat mechanics (reducing risk of physical harm) and sex mechanics (reducing intimacy-based discomfort). I comment on them briefly, as they are undeniably related to player safety, although not typically counted among 'safety mechanics' per se. My main point of interest are non-representational safety mechanics used to communicate discomfort, negotiate boundaries, regulate intensity, and pause/break the game in emergency (Koljonen 2016a, 2016b). 
Generally speaking, player safety has been increasingly emphasised in the larping community, with new mechanics reflecting the changing rhetorics. I can see a steady chronological trend in the last decade, with safety concerns widely expanding in the area of emotional safety and mental health; safety policies changing priorities from reaction to prevention; and responsibility being shifted from the recipient to the initiator of risky behaviour. I do not want to divide the process into precise periods, as any periodisation in creative arts runs the risk of oversimplification. Instead, I will demonstrate the changing trend in rhetorics/mechanics with examples from around 2010, around 2014, and 2016+.

Not all larp mechanics are dictated by safety concerns. Some serve as means of representing actions or effects which are impossible to perform as physical live action: supernatural powers (flying, spellcasting, mind control) or futuristic high-tech which does not yet exist, or is unavailable to larp organisers. This kind of mechanics is beyond the scope of my paper. Instead, I focus on mechanics that replace live (inter)actions which players could actually perform 'for real' - but choose not to due to safety concerns. These concerns fall into three main areas.

Risk of physical harm. Larp is physically enacted in interactions between people, objects, and locations. This entails the usual risk of accidents, such as tripping on the stairs or slipping on wet grass. This risk gets unusually heightened in more dangerous larp locations, featuring ruined buildings (more risk of tripping and falling in the rubble), bodies of water (risk of drowning), etc. It also gets heightened in larps that encourage fast movement (running) and/or low visibility (e.g. at night). Moreover, many larps feature physical combat; however safe the fake weapons may be, there is still a risk of pain and bruising, not to mention standard sport injuries such as a sprained ankle. This risk is typically mitigated by combat mechanics: a set of rules replacing actual violence with fake violence, or even with symbolic non-contact operations with cards or numerical parameters.

Erotic intimacy. Many larps include romantic and sexual relationships (Brown \& Stenros, 2018). Some specifically emphasise desire and sexuality; in others, romance and intimacy may be spontaneously initiated by players. In either case, larpers may face intimate role-play, ranging all the way from flirting and courting to consensual sex to gang rape (which is extreme 
and rare, but not unheard of; see Algayres, 2019). Given that people have radically different boundaries of (dis)comfort with eroticism, nakedness, and skin-to-skin contact, role-played intimacy constitutes another aspect of larp safety. If larps feature sex scenes, they typically introduce sex mechanics. Analogically to combat mechanics, sex mechanics replace actual bodily performance with codified theatrical or symbolic gestures.

Psychological trauma. Larpers are at risk of potentially traumatising experiences of bullying, harassment, racism, humiliation, etc., which may happen both as part of the fictional in-character role-play, or on the level of real-world social interaction between players. These risks are mitigated by various means: pre-larp workshops, policy statements, post-larp debriefings, off-game rooms which the player can retreat into, interventions from the organisers - and also by safety mechanics.

Combat and sex mechanics are codified rules for non-explicit representation of violence or sex among the role-played characters. Safety mechanics, by contrast, are non-representational: codified rules for metacommunication and interaction between players. They are designed to stop, deescalate, or otherwise calibrate the intensity of play. Both types often co-exist and may activate each other. A safety mechanic may be used to initiate a specific representational mechanic for sex or combat, and vice versa: too intense engagement in sex or combat mechanics may make the co-player resort to a safety mechanic to end the uncomfortable interaction. But safety mechanics cover much more ground than sex and violence: they may regulate any aspect of role-playing, e.g restrict or remove narrative content, if it touches upon too sensitive issues.

In the Nordic tradition, larp has been considered a serious form of expression akin to film and literature, capable of tackling difficult, controversial, and potentially traumatic issues (Stenros, 2010; Stenros \& Montola, 2010; Zagal \& Deterding, 2018; Harviainen et al., 2018). Larps have addressed all kinds of social anxieties, phobias, problems and traumas: immigration, war, military occupation, religion, cultural differences, cancer, mental illness, homosexuality, prostitution, fatphobia, and many more. Players impersonate and emotionally identify with victims and/or perpetrators of abuse and trauma, experiencing stressful face-to-face interactions coupled with social pressure. Naturally, it does not happen in every larp. Action-intense combat larps, fantasy larps for children, and 
edularps for businesspeople are not (typically) designed to touch upon sensitive content. But many larps are. Moreover, emotionally stressful and traumatising situations may happen also in larps created purely for entertainment, emerging from player-to-player interactions without (or against) the expectations of the designers. Consequently, players' emotional/psychological safety is increasingly covered in larp-related debates - and affects the choice of mechanics by larp designers.

In this paper I am leaving sex and combat mechanics aside in order to focus on non-representational safety mechanics, They range from the decades-old safety words to 'consent \& calibration' mechanics developed around 2015.

\section{Mechanics in larp}

To put safety mechanics in context, let me briefly discuss larp mechanics in general. Many larps include game mechanics similar to board games, tabletop RPG, and computer RPG, equipping players with character sheets listing physical, mental, and supernatural abilities and skills, frequently with numerical statistics. Due to full-body movement and interactions in/with the physical environment, mechanics such as rolling dice or moving pieces on the board are less convenient (thus hardly ever used) in larp than in tabletop games (Zagal \& Deterding, 2018, p. 34). More often can one come across playing/drawing cards: a small deck/hand can be carried around and handled discreetly by showing or exchanging from hand to hand, without a need to sit down or use a table(top). Larp-friendly mechanics based on game components and attributes include (and are not limited to) simple comparison of statistics with 'the higher number wins', 'paper-rock-scissors' contests to resolve ties, or 'skill calls' when the player verbally declares which skill/ability they are activating. Some mechanics are based on agility, such as 'life straps' (straps of paper) attached to the chest which enemies try to tear off in combat, or painted tree cones as magical spells to be hand-thrown at targets and working only when hit. They all are variants of "explicit rule-based operations on game components and pre-defined attributes" Mochocki, 2021, p. 132): a repertoire larp shares with boardgaming and tabletop RPG (though it is perhaps 
easier to find agility-based mechanics in board games than dice-rolling and piece-moving in larps).

The above-mentioned mechanics are universally acknowledged as 'mechanics', both due to larp practice and by analogy with non-digital tabletop games. Most typically, they include rules for character generation and progression, and rules for combat and supernatural confrontation. But it becomes less obvious in the case of representational conventions such as WYsIWYG, DKwDK and DKWDDK. WYsIWYG (What You See Is What You Get) assumes that the player's appearance and actions correspond with the appearance and actions of the role-played character. There are no symbolic game mechanics such as a hand-thrown pine cone standing for a magic missile. This is essentially the same as the German convention DKwDDK (Du Kannst Was Du Darstellen Kannst/You Can Do What You Can Represent): the player can undertake any in-game action that they can believably perform via acting and props. For example, mending armour or healing wounds may be performed if the player can act it out with the use of prop tools in a way that appears realistic. DKwDK (Du Kannst Was Du Kannst/You Can Do What You Can Do) is more limited: the player can only take actions they can really perform - no pretend-play acting. Elsewhere, I have named these two representational conventions 'live action' (DKWDK) and 'live acting' (DKWDDK) (Mochocki, 2017). In the larp community, the WYSIWYG/DKWDK/DKWDDK conventions are sometimes called mechanics (e.g. HalflingSkyPirate 2015). However, wYSIwYG/DKWDK are also described as 'no mechanics' - just genuine live-action. For instance, the DKWDK policy announced by Kto ty? 2 (2018) was met with harsh criticism on the Facebook "LARP Poland" group for not using any mechanics for combat and sex.

Yet another type of larp mechanics is used for off-game/metagame communication between players; some of these are called 'safety and calibration' mechanics. They change off-game/in-game status (e.g. pausing the game or quitting a scene), or the way the game state is represented (enacted) in role-play (e.g. to reduce physical contact). Sometimes calibration mechanics are used to reject or cancel afforded interactions (e.g. refusing to role-play intimate moments). In this case, the game state - i.e. events (not) happening to characters in the game world - will also be affected. The safety mechanics I discuss below - in correlation with safety rhetorics - are of the kind described in this paragraph: they work as metacommunication 
between players, its aim being to signal discomfort, negotiate intensity, pause/stop the game, etc., in order to avoid or minimise stress or harm.

\section{Around 2010: Safe words. Embracing the risks. Recipient's responsibility}

In the 2000s, Nordic larp was widely considered to be risky, judging by the publications from 2000-2011, including the Knutepunkt/Solmukohta conference books, the Playground magazine, and the main book-length works. More than that, the risk seemed to be accepted. In the larp Hamlet (2002), for instance, "The concern for safety was almost zero; there was too much alcohol... in combination with firearms... use of pornography... (semi) public sex by consenting adults" (Bergström 2010, p. 139). In 2010 the author concludes, "There must never be another Hamlet like this one" (p. 139). In 2012, Järvelä notes that "the admiration for hardcore gaming has diminished but it is still a prevailing attitude beneath the surface" (p. 23).

Three intensely discussed terms from this period of larp theory and practice were alibi, bleed, and immersion:

- Alibi as justification for adult engagement in the seemingly childish pretend play and also for doing immoral, dangerous, or frankly evil things under the guise of larp characters (Montola \& Holopainen, 2012).

- Bleed as the emotional spillage from the larp to post-larp life (Stenros \& Bowman, 2018), such as mourning the loss of fictional in-larp friends, or being shaken the whole day after a scene of humiliation.

- Immersion as the psychological state of being so deeply involved in role-playing that the players almost forgot their real selves to adopt the personas (Bowman, 2018).

Championed by the Turku School Manifesto (see Pohjola, 2003), immersionism was the biggest trend in Nordic larping (Harviainen, 2006) as the primary creative agenda for larp designers and the most desired experience for players. Immersion, bleed, and alibi are interconnected (Bowman, 2018):

- Immersion provides an alibi for in-larp risky behaviour ("It wasn't me, it was my character"). 
- The intense emotions of immersive role-play cannot abruptly stop but will 'bleed' for some time after the game.

- The intensity of immersion + bleed allows for a deep first-hand experience of somebody else's situation, which supports empathy, understanding, critical thinking, etc., thus providing an alibi for larping as a form of social education and self-development.

The publications were filled with accounts of, and ideas for, cuttingedge larps that would confront players with stress and potential trauma to test their boundaries. For instance, KAPO (2011) cast players as prisoners or guards in a detention camp, where the prisoners were subjected to systemic abuse and dehumanisation. The game was designed to push the players' boundaries very hard - but also offered a safe off-game room for those who could not take it any longer. A traumatised player could quit the game entirely, or take a break in the off-game room with coffee, hugs and friendly conversation and then go back to the game (see Raasted, 2012).

Probably the most controversial game was Gang Rape (2008), a narration-based role-play between one victim and several rapists. While not actually a larp, it emerged in the Nordic larp community and - thanks to Montola's (2010) academic paper - became a major reference point for a 'positive-negative experience' in role-playing. Its participants reported highly negative (frankly, horrible) experiences during gameplay, but they also gave the game highly positive overall evaluation as an educational and thought-provoking experience. So it was commonly accepted that many larp experiences would be uncomfortable, and some would be deeply unpleasant, bringing the player to tears and leaving them emotionally shaken. When boundaries are being pushed, it is inevitable they will be overstepped every now and then. Emotional safety concerns in games like Kapo (2011) did not try to prevent this from happening - only to provide care and support when it did. This was done by off-game rooms manned by organisers offering emotional support, by pre-larp workshops (known in Denmark since 2005; see Pre-larp Workshop, 2013), and by further care and support in a formal debriefing after the game (Bowman, 2014).

This view on larp safety goes hand in hand with some popular larp mechanics, the main example being 'safe words', present in Nordic larp since the 1990s (Fatland, 2013). One typical set of safe words in larp is "cut - brake" (Stark, 2014): when a player feels that the interaction is too 
intense (because of physical pain, emotional trauma, or whatever reason), they can say "cut" or "brake", obligating the involved partner(s) to comply. "Cut" stops the interaction immediately; "brake" only reduces the level of intensity. In the 'traffic lights' version safe words are "green - yellow red"; "red" works like "cut"; "yellow" means "don't push further" (i.e. the interaction is on a tolerable level but on the verge of getting too intense); and "green" asks for increased intensity (Niskanen 2017, p. 20).

This larp mechanic - if used as the only one - puts the responsibility for signalling discomfort on the person who experiences it. If the larp is supposed to be a stressful ground for testing others' (and one's own) boundaries, the initiator of the action is free to push harder until told to stop or slow down. Järvelä (2012) put it bluntly: "It is irresponsible towards other players to not know your limits as you are then practically enabling them to go too far, which is something that they do not want either" (p. 23). With regard to organiser responsibility, Järvelä (2012) insisted they should actively create the culture of support for communicating one's limits, for using safe words whenever necessary, and for leaving the game entirely when situation becomes too uncomfortable. The organisers should first arrange the space to discuss boundaries before the game, and then conduct a debriefing. Nonetheless, for all these supportive actions by the organisers, "it is the responsibility of each individual player to be clear enough on communicating her own limits to others" (ibid.).

It is symptomatic that safety words were the only well-known safety mechanics that appeared in player safety publications around 2010. I will not write "the only existing one", as it is quite possible that larp designers experimented with more ideas. But it is the only one that surfaced in the safety discourse next to representational sex mechanics and nonmechanical safety measures (such as debriefings, off-game rooms, etc.). The ok-check would not gain recognition until 2012.

\section{Around 2014: OK-check. Mitigate the risks. Shared responsibility}

Somewhere around 2012-2014 the general view on safety apparently shifted towards a shared responsibility for controlling the risk - shared 
between the initiator and the target of the interaction. Proponents of safety largely rejected the view that the player should be responsible for knowing and communicating their limits beforehand. This change is best illustrated by the above-cited paper by Järvelä (2012), reprinted two years later in a collection entitled The Foundation Stone of Nordic Larp. In 2012 he wrote: "Structured discussion about suitable limits will ensure that everyone involved is aware of others' (and their own) limits" (23). In 2014 he declared in a brief preface to the reprinted text: "I should have emphasized how unfamiliar even experienced players are with their own behaviour and emotional reactions in more stressful conditions" (p. 169), and acknowledged that "systemic features can direct situations into unpleasant and unforeseen territories despite everyone's best intentions" (ibid.). The dominant view around 2014 assumed that people cannot fully predict how they would feel and behave, therefore it is not enough to rely on pre-game declarations.

Panelists in "The Great Player Safety Debate" at the Solmukohta 2012 conference discussed the already-practiced safety tools (safe words, pre-larp workshops, off-game rooms, debriefing), and found it important to develop the toolbox further (Stark, 2012b). An important rule (not a mechanic) was "Don't be an asshole", which meant "caring about other people's feelings", and being "sensitive to others' social and physical boundaries so that you do not cross them during play" (Stark 2014). Proponents of larp safety increasingly demanded that players should be allowed not to have their boundaries pushed - they should be able to opt-out of any scene or interaction they are uncomfortable with. For instance, Fatland (2013) encouraged "the 'door is open' principle: if the play discomforts you, you are free to leave", and "the 'no questioning' rule: if someone leaves, or says [cut] or [brake], we don't question their reasons for doing so". So did Järvelä (2012, p. 23).

The increased pressure on safety might be related to the globalisation, and perhaps Americanisation, of Nordic larp in 2012-2015. Until 2010-2011 the two communities remained in relative isolation. No American games were covered in the 2010 book Nordic Larp by the Finnish larp scholars (Montola \& Stenros, eds.), and nothing Nordic was mentioned in The Functions of Role-Playing (2010), a book by Sarah Lynne Bowman, a leading us-based larp scholar. Two years later Bowman attended the 
Role-Playing Games Seminar at University of Tampere and the Solmukohta larp conference in Finland. So did Lizzie Stark, an American journalist and activist, whose 2012 larp book Leaving Mundania was distributed in the us and in Nordic lands. Stark's blog Leaving Mundania became an online 'contact zone' between the regions. The title of the 2012 Nordic larp conference book was States of Play: Nordic Larp Around the World, acknowledging the fact that 'Nordic' (or serious, avant-garde, self-reflexive, and socially involved) larp was no longer limited to Northern Europe.

Then, November 2014 brought the first College of Wizardry, a highproduction value ('blockbuster') Harry Potter-themed larp by a DanishPolish team, attended by an international audience, and winning a stunningly worldwide coverage by mainstream media (Axner 2014). It started a whole genre of 'blockbuster castle larps', creating a new branch of tourism in Poland (Dembiński, 2016). This was a milestone in the professionalisation of larp as an entertainment medium: one that is capable of supporting big budgets, sustainable businesses, full-time careers, and global audiences.

All in all, the years 2012-2014 drastically increased the internationalisation and professionalisation of the Nordic larp scene - including Nordic-American collaboration. American scholars and designers became influential voices in the Nordic community, and popularised the Nordic larp tradition in the us. Blockbuster castle larping brought American players to European larps in unprecedented numbers. This also extended to cross-Atlantic collaboration between larp designers and organisations, including plans for a us-based spin-off of College of Wizardry named New World Magischola. Some larps had repeated runs in the us and Nordic countries. There is also an American equivalent of Knutepunkt/Solmukohta: the Living Games Conference (since 2014), reciprocally lending the floor to Nordic voices.

The shift away from high-risk immersionism towards a less-risk safety culture is best reflected by the 'ok check-in' mechanics, whose origins Brown locates in "some us larp circles in 2009 or 2010 ". The New World Magischola team in 2015 decided to adapt this tool for their first run (Brown 2016). It consists in a quick exchange of hand gestures, started by the person who is inflicting an intense unpleasant interaction on another player. If the initiator suspects they might be putting too much 
pressure on the fellow player, they show them the "ok" gesture with one hand: a silent question "Are you ok?". This may happen, for example, if the target player cries and begs for mercy and the initiator is not sure if this is role-played or real. In the 2016 version of this mechanics, the target player will respond with a thumbs-up if they want the interaction to continue, thumbs-down if they have had enough, or a flat hand meaning "I'm not sure" (which the active player should take as a thumbs-down nonetheless). These mechanics are not supposed to be the only tool used; they should coexist with safe words and/or tapping out so that the target player could communicate their discomfort whenever they need, not waiting for an ok-check.

OK check-in was extensively discussed around 2012-2014 in the American larp community, with many us-based players criticising these mechanics as harmful to character immersion. A player deeply immersed, for instance, in the role of a prisoner abused by a guard - and enjoying this intense immersion - would not like the abusive guard to ask if everything is ok. Enthusiasts of the ok-check mechanics insist that the exchange of two gestures is so quick and non-invasive that it hardly impacts character immersion (Bowman, 2017). Many immersionists disagree. A need for such a quick check-in code was declared in the player safety panel at Solmukohta 2012 (Stark, 2012b), postulated online by Stark (2014), and was soon to become a standard in the larp design toolbox.

\section{2016 and 2016+: Consent \& calibration. Avoid all risks. Initiator's responsibility}

"Two or three of the currently most influential techniques or concepts in player safety and playstyle calibration... were invented or significantly iterated in literally the last half year", writes Koljonen (2016a) in September 2016. This included new mechanics similar to the good-old safe words: ones that allow a distressed player to signal discomfort and pause the game to either exit or deescalate a scene. One such mechanics is 'tapping out' in which "you tap your co-player's arm or another convenient part of their body twice, ... as many times and as hard as you need to get their attention" (Koljonen 2016b), at which point the tapped player should 
stop their action and allow the tapping one to leave, or to reengage with a lower intensity. In the 'See no evil' aka 'Lookdown' mechanic "you raise your hand clearly in front of your eyes like the See No Evil monkey" (Koljonen 2016c). It is important that "there should be no questions asked, no explanation needed or demanded, and no consequences given... Person 1 shields their eyes and walks away. Person 2 (and all other people...) ignore Person 1's exit and continue as usual" (Brown 2017a, 70).

New World Magischola, debuting in 2016, was a milestone in larp safety, employing a huge set of old (safe words), not-that-old (ox check-in) and brand new ('see-no-evil') safety and calibration mechanics (Brown, 2016), in addition to a 12-page long legal form. Soon after that, Maury Brown, one of the lead organisers and a dedicated proponent of larp safety, penned The Consent and Community Safety Manifesto (2017b), prescribing 40 detailed commitments for players or larp designers. She also called for the appointment of formal safety officers in larps, as did Bowman, Brown, Atwater, \& Rowland (2017).

Another big Nordic-American role-playing franchise that adopted safety policies from Brown, Bowman and Koljonen was World of Darkness, with larps such as End of the Line and Enlightenment in Blood. At the World of Darkness Berlin convention in May 2017 all participants (myself included) were required to attend 3-hour pre-larp workshops in which safety policies were discussed and safety mechanics practiced. In addition to the ok check-in, tapping out, and see-no-evil, the convention featured a novelty - 'consent mechanics'.

Consent mechanics is used before potentially uncomfortable interactions to ask for explicit consent. In the 2017 Vampire larps in Berlin, it was mandatory in three situations: violence, intimacy, and feeding (i.e. vampiric bloodsucking). If a player wanted to initiate one of these interactions, they should ask off-game: "violence?" or "feeding?" or "sexuality"? If the target player said "no, thanks", the scene should not be initiated at all. If they said "yes, please", the involved players should explicitly discuss how they wanted to enact it, setting boundaries on the degree of brutality, skin-to-skin contact, or nakedness. In each case, intensity should be brought to the lowest level acceptable for all participants. This discussion was to take place off-game between players (not characters), who would stop role-playing for however long it took to settle the details. 
Needless to say, if the brief off-game exchange of 'ok check-in' gestures was seen as detrimental to immersion, even more so may be said about prolonged off-game negotiations required by consent mechanics. Concerns for safety thus will sometimes directly clash with concerns for immersion (Bowman, 2017; Maersk, Cecilia, Rotvig, \& Berner, 2019).

A less invasive version of consent culture, "sometimes called bullettime consent" (Koljonen, 2016a) relies on the principles of 'telegraph your intent' (do not grab co-players by surprise, approach them openly) and 'escalate slowly' (start with low intensity and increase gradually), the aim being to give co-players time to opt out or signal discomfort. I am not sure if these principles are actually 'mechanics'; I am more inclined to call them 'rules' regulating interactions. Still, they emerge from the same safety rhetorics.

\section{The Future of larp and larp safety}

One obvious trend is the professionalisation of larp as an entertainment industry and educational technology. Its long history (Knutepunkt, since 1997) of internationally developed self-reflexive theory, design tools, and principles has produced a community of designers, organisers, educators, manufacturers, etc., with a plethora of amateur, professional, academic, and semi-academic publications and events, e.g. Edularp Conference (starting in 2014) and Larp Designers Conference (in 2016). Larp is making its way in the experience design industry, with larp designers as the driving force behind the high-profile conference called The College of Extraordinary Experiences (since 2016). Larp was not yet mentioned in the Immersive Design Industry 2019 report but I expect it to feature in the next editions soon. Another professional venue for larp is education, both for schools (Vanek \& Peterson, 2016) and corporate clientele (Branc \& Mochocki, 2018), with Nordic larp seen as a variant of serious games (Branc, 2018, Chapter 3).

It comes as no surprise that increased professionalisation has put safety high on the agenda. If frequency of words in Knutepunkt/Solmukohta books may be any indication, the 146 pages of the 2010 book include 'safety' merely 3 times (o,02 per page), compared to 21 times on 
200 pages in 2014 (o,10 per page), 31 times on 168 pages in 2016 (o,18 per page), and 104 times on 243 pages in 2018 (o,42 per page).

The Nordic-American discourse on larp safety seems to have reached its peak in 2016-2017 with Brown's manifesto (2017b) featuring a long list of prescriptive commitments. One of the clearly rising trends is professionalising the safety practices through codification, formalization, and standardisation. A recent example is the Larp Counselor Code of Ethics (Atwater \& Rowland, 2018), even more authoritative in its usage of "must", "always", "never" and "only" than Brown (2017b). Another noticeable trend is resistance and negotiation with these universalising ambitions. One thing is an internal debate within the 'safety culture', with Brown's ideas criticised as inefficient and self-defeating on the grounds of safety itself (Webb, 2018). Another thing is the clash of that manifesto with competing ones:

- from Poland, rejecting any design approach or policy as universally binding (Bartczak et al., 2015);

- from Italy, making "Play unsafely!" its number one principle (Chaos League, 2016);

- from Brazil, its first principle being "To play is to touch", which bluntly speaks against "an Eurocentric vision (some will say colonialist)" (Iuama, 2018).

The most recent (2019) Larp Safety Manifesto is much less dogmatic than the 'must-nevers' and 'should-alwayses' of Atwater \& Rowland (2018). It is not clear to what extent the manifesto "made at Knudepunkt 2019" actually represents the Knudepunkt or Nordic community, but it is available on major Nordic larp websites with the Knudepunkt 2019 label. This suggests a support extending beyond the four signed authors. The manifesto insists that all safety issues should be discussed and shaped according to the needs of the player base, varying as they do between cultures and traditions. "We promise to have a discussion about how we approach the balance between immersion and need for safety" (Maersk, Cecilia, Rotvig, \& Berner, 2019) is a declaration that does not clearly prioritise either. It sounds open to some reduction of safety in the name of immersion (unlike "immersion should never be prioritized" in Atwater \& Rowland, 2018). Coming from the cradle of Nordic larp theory, it demonstrates that prescriptive dogmatism has not been universally 
adopted. The rich repertoire of safety mechanics and policies allows for selection and calibration to support any playstyle.

This is what I predict as the future of larp safety: various larp circles choosing such configurations of safety mechanics that best reflect their creative vision and safety rhetorics. They will be (as they are) running the gamut from 'radical immersionism' to 'radical safetyism', with inevitable disputes and conflicts. There will be larps opting for maximum safety like New World Magischola (2016), developing ever-expanding codes of conduct, protocols, best practices, and trained counselors, and aiming to normalise their safety culture worldwide. And there will be larps that consciously adopt a higher risk-level and accordingly reduce safety infrastructure, like Kto ty? 2 (2018), whose only mechanic was safe words. Now the roleplaying terminology recognises 'rules-light' and 'rules-heavy' games, denoting low or high complexity of gameplay mechanics. It remains to be seen whether 'safety-light' (or hardcore) and 'safety-heavy' will develop as two equally valid styles, or whether 'unsafe' larping will be condemned as unprofessional.

The most recent controversy about safety in professional (in this case: educational) larp emerged in July 2020, sparked by a student-teacher conflict over RTTP role-play at the University of North Carolina. Reacting to the Past is essentially an edularp pedagogy (Vanek \& Peterson, 2016) that does not self-identify as larp. It was developed outside the larp community by Mark Carnes (2014) under the name of role-immersion games. RTTP is employed at many universities to teach history, culture, social studies, etc. The UNC controversy, as reported by Katsanis (2020), rose about reverse role-switching: a white student impersonating a black character. Acting-as-black turned out to be unacceptable to a genuinely black student in the sociology class, who reported it to university administration as blackface and minstrelsy.

The subsequent discussion I witnessed on a Facebook group of edularp professionals pointed to two largely-impossible challenges: to design historical edularps so that every student in class would role-play as their own ethnicity, and to make sure that no racially insensitive behaviour would emerge in improvised play among the participants. Some experienced edularpers even started to question the validity of using historical edularps at all, given the number of unresolvable safety issues (Mochocki, 
2021, p. 260). The UNC example is not the only such case; it echoes negative reactions to the us run of Just a Little Lovin', a Norwegian larp about the New York gay community struck by AIDS in the 1980s, which was analogically inveighed against. As Torner (2017) reports: "We were told that the Norwegians, even gay Norwegians, had no right to this shared history, and that this was a 'gay larp for straight people,' implying a kind of shameful blackface-level mimicry of a certain vulnerable community" (p. 55). The problem is not limited to historical worlds: "Larp designers who choose a real-world setting - historical or contemporary - are faced, whether they realize it or not, with a set of decisions about how to portray the social prejudices", warns Holkar (2016). Thus, with historical role-play now flagged in the us as "unsafe learning environment" (Katsanis 2020), edularp professionals may find themselves in a tight spot. This safety issue lies in the core of role-playing as an activity, therefore it is not likely to be solved by any mechanics.

\section{References}

Algayres, M. (2019). The Evolution of the Depiction of Rape in Larp. Retrieved from Nordic Larp website: <https://nordiclarp.org/2019/05/20/ the-evolution-of-the-depiction-of-rape-in-larp/>.

Axner, J. (2014). College of Wizardry 2014 Round-up. Retrieved from Nordic Larp website: <https://nordiclarp.org/2014/12/o9/college-ofwizardry-2014-round-up/>.

Bartczak, K., \& et al. (2015). Post-Progressive Larping Manifesto. Retrieved from Argos Blog website: <http://www.argos.edu.pl/en/miscellanea/178manifest-larpingu-post-progresywnego $>$.

Bergström, K. (2010). Hamlet. In J. Stenros \& M. Montola (Eds.), Nordic larp (1st print, pp. 133-141). Stockholm: Fea Livia.

Board Game Mechanics. (n.d.). Retrieved from BoardGameGeek website: <https://boardgamegeek.com/browse/boardgamemechanic>.

Bowman, S. L. (2010). The Functions of Role-Playing Games: How Participants Create Community, Solve Problems and Explore Identity. Jefferson, N.C: McFarland \& Co. 
Bowman, S. L. (2014). Returning to the Real World. Retrieved from Nordic Larp website: <https://nordiclarp.org/2014/12/o8/debrief-returningto-the-real-world/>.

Bowman, S. L. (2017). A Matter of Trust - Larp and Consent Culture. Retrieved from Nordic Larp website: <https://nordiclarp.org/2017/02/03/ matter-trust-larp-consent-culture/>.

Bowman, S. L. (2018). Immersion and Shared Imagination in Role-Playing Games. In J. P. Zagal \& S. Deterding (Eds.), Role-Playing Game Studies: Transmedia Foundations (pp. 379-394). New York: Routledge.

Bowman, S. L., Brown, M., Atwater, B., \& Rowland, A. (2017). Larp Counselors: An Additional Safety Net. Retrieved from Nordic Larp website: <https:// nordiclarp.org/2017/08/o7/larp-counselors-additional-safety-net/> .

Branc, B. (2018). Imagine This: The Transformative Power of Edu-Larp in Corporate Training \& Assessment (M. Mochocki, Ed.). Retrieved from $<$ https://www.researchgate.net/publication/323812997_Imagine_This_ executive_summary>.

Branc, B., \& Mochocki, M. (2018). Imagine This (Executive Summary). In M. Mochocki (Ed.), Imagine This: The Transformative Power of Edu-Larp in Corporate Training \& Assessment (pp. 8-19; By B. Branc). Retrieved from <https://www.researchgate.net/publication/323812997_Imagine_This_executive_summary>.

Brigante, R. (2019). Interactive, Intimate, Experiential: The Impact of Immersive Design. 2019 Immersive Design Industry Annual Report (N. Nelson, Ed.). Retrieved from <https://immersivedesignsummit. com/2019industryreport.pdf $>$.

Brown, A. M. L., \& Stenros, J. (2018). Sexuality and the Erotic in Role-Play. In J. P. Zagal \& S. Deterding (Eds.), Role-Playing Game Studies: Transmedia Foundations. New York: Routledge.

Brown, M. (2016). Creating a Culture of Trust through Safety and Calibration Larp Mechanics. Retrieved from Nordic Larp website: <https:// nordiclarp.org/2016/09/09/creating-culture-trust-safety-calibrationlarp-mechanics/>.

Brown, M. (2017a). Safety and Calibration Design Tools and Their Uses. In A. Waern \& J. Axner (Eds.), Shuffling the Deck: The Knutpunkt 2018 Printed Companion (pp. 65-76). Pittsburgh, PA: ETC Press. 
Brown, M. (2017b). The Consent and Community Safety Manifesto. Retrieved from Nordic Larp website: <https://nordiclarp.org/2017/03/24/ the-consent-and-community-safety-manifesto/>.

Carnes, M. C. (2014). Minds on Fire: How Role-Immersion Games Transform College. Harvard University Press.

Chaos League (2016). Introduction to Southern Way - New Italian Larp. Retrieved from Nordic Larp website: <https://nordiclarp.org/2016/05/30/ introduction-southern-way-new-italian-larp/>.

Dembiński, D. (2016). Świat larpowej turystyki. In P. Milewski (Ed.), Nasiona. Drzewa. Ogrody. (pp. 147-152). Warszawa: Stowarzyszenie Twórców Gier FUNREAL.

Fatland,E. (2013,June 26). Notes on Kutt, Brems and Emotional Safety. Retrieved from The Larpwright website: <http://larpwright.efatland.com/?p=339>. HalflingSkyPirate (2015). "Du Kannst Was Du Darstellen Kannst" - The perfect LARP mechanic. Retrieved from Reddit website: <https://www. reddit.com/r/LARP/comments/3rkea6/du_kannst_was_du_darstellen_ kannst_the_perfect/>.

Harviainen, J. T. (2006, October). Information, Immersion, Identity. The Interplay of Multiple Selves During Live-Action Role-Play. Journal of Interactive Drama, 1(2), 9-52.

Harviainen, J. T., Bienia, R., Brind, S., Hitchens, M., Kot, Y. I., MacCallumStewart, E., Sturrock, I. (2018). Live-Action Role-Playing Games. In J. P. Zagal \& S. Deterding (Eds.), Role-Playing Game Studies: Transmedia Foundations (pp. 87-106). New York: Routledge.

Holkar, M. (2016). Larp and Prejudice: Expressing, Erasing, Exploring, and the Fun Tax. In J. Särkijärvi, M. Loponen, \& K. Kangas (Eds.), Larp Realia - Analysis, Design, and Discussions of Nordic Larp (pp. 95-101).

Iuama, T. R. (2018). The Jeitinho Brasileiro Manifesto. Retrieved from Nordic Larp website: <https://nordiclarp.org/2018/12/29/the-jeitinhobrasileiro-manifesto/>.

Järvelä, S. (2012). The Golden Rule of Larp. In J. Pettersson (Ed.), States of Play: Nordic Larp Around the World (pp. 19-24). Helsinki: Pohjoismaisen roolipelaamisen seura.

Järvelä, S. (2014). The Golden Rule of Larp. In E. Saitta, M. Holm-Andersen, \& J. Back (Eds.), The Foundation Stone of Nordic Larp: Knutpunkt 2014 (pp. 169-175). Knutpunkt. 
Katsanis, A. (2020, July 7). UNC Professor Accused of Ignoring Students of Color's Concerns over Role-Playing Class. The Daily Tar Heel. Retrieved from <https://www.dailytarheel.com/article/2020/07/sociology-professor-racism-allegations-0707>.

Knutepunkt (2019). In Nordic Larp Wiki. Retrieved from <https://nordiclarp.org/wiki/Knutepunkt>.

Koljonen, J. (2016a, September 9). Toolkit: The ok Check-In. Retrieved from Safety in Larp website: <https://participationsafety.wordpress. com/2016/og/og/toolkit-the-ok-check-in/>.

Koljonen, J. (2016b, September 11). Toolkit: The Tap-Out. Retrieved from Safety in Larp website: <https://participationsafety.wordpress. com/2016/og/11/toolkit-the-tap-out/>.

Koljonen, J. (2016c, September 18). Toolkit: The “See No Evil” or Lookdown. Retrieved from Safety in Larp website: <https://participationsafety. wordpress.com/2016/og/18/toolkit-the-see-no-evil-or-lookdown/>.

Live action role-playing game. (2019). In Wikipedia. Retrieved from $<$ https://en.wikipedia.org/wiki/Live_action_role-playing_game>.

Mærsk, E., Cecilia, L., Rotvig, K., \& Berner, A. (2019). Larp Safety Manifesto. Retrieved from Nordic Larp website: <https://nordiclarp. org/2019/02/15/larp-safety-manifesto/>.

Mochocki, M. (2017). From Live Action to Live Perception: Player Character's Point of View. In Y. I. Kot (Ed.), Larp as a Social Tool (pp. 147-167). Retrieved from <https://www.researchgate.net/publication/322150718_ From_Live_Action_to_Live_Perception_Player_Character\%27s_Point_ of_View>.

Mochocki, M. (2021). Role-Play As a Heritage Practice: Historical LARP, Tabletop RPG and Reenactment. Abingdon \& New York: Routledge.

Montola, M. (2010). The Positive Negative Experience in Extreme RolePlaying. In Digra Nordic'10: Experiencing Games: Games, Play, and Players (pp. 1-8). Retrieved from <http://www.digra.org/digital-library/publications/the-positive-negative-experience-in-extreme-role-playing/>. Montola, M., \& Holopainen, J. (2012). First Person Audience and the Art of Painful Role-Playing. In E. Torner \& W. J. White (Eds.), Immersive Gameplay: Essays on Participatory Media and Role-Playing (pp. 13-30). Jefferson, N.C: McFarland \& Co. 
Niskanen, N. (2017). Safer Larping. A Package of Materials to Combat and Prevent Harassment (A. Joensuu, Trans.). Retrieved from <https://turvallisempaa.files.wordpress.com/2017/06/safer_larping_package_v1.pdf>. Pettersson, J. (Ed.). (2012). States of Play: Nordic Larp Around the World. Helsinki: Pohjoismaisen roolipelaamisen seura.

Pohjola, M. (2003). The Manifesto of the Turku School. In M.Gade, L. Thorup, \& M. Sander (Eds.), As Larp Grows Up: Theory and Methods in Larp (pp. 32-43). Frederiksberg: Projektgruppen кро3.

Pre-larp Workshop. (2013). Retrieved from Nordic Larp Wiki website: $<$ https://nordiclarp.org/wiki/Pre-larp_Workshop>.

Raasted, C. (Ed.). (2012). The Book of Kapo. Copenhagen: Rollespilsakademiet.

Stark, L. (2012a). Leaving Mundania: Inside the Transformative World of Live Action Role-Playing Games. Chicago: Chicago Review Press.

Stark, L. (2012b). Player Safety in Nordic Games. Retrieved from Leaving Mundania. Inside the World of Larp website: <http://leavingmundania. com/2012/04/26/player-safety-in-nordic-games/>.

Stark, L. (2014a, February 27). A Primer on Safety in Roleplaying Games. Retrieved from Leaving Mundania. Inside the World of Larp website: $<$ http://leavingmundania.com/2014/02/27/primer-safety-in-roleplaying-games/>.

Stark, L. (2014b, April 29). How to Become a Better Larper. Retrieved from Leaving Mundania. Inside the World of Larp website: <http://leavingmundania.com/2014/04/29/become-better-larper/>.

Stenros, J. (2010). Nordic Larp: Theatre, Art and Game. In J. Stenros \& M. Montola (Eds.), Nordic larp (1st print, pp. 300-315). Stockholm: Fea Livia.

Stenros, J., \& Bowman, S. L. (2018). Transgressive Role-Play. In J. P. Zagal \& S. Deterding (Eds.), Role-Playing Game Studies: Transmedia Foundations. New York: Routledge.

Stenros, J., \& Montola, M. (Eds.). (2010). Nordic Larp. Stockholm: Fea Livia. Stenros, J., \& Montola, M. (2010). The Paradox of Nordic Larp Culture. In J. Stenros \& M. Montola (Eds.), Nordic Larp ( $1^{\text {st }}$ print, pp. 15-29). Stockholm: Fea Livia.

Torner, E. (2017). Just a Little Lovin' USA 2017. In A. Waern \& J. Axner (Eds.), Shuffling the Deck: The Knutpunkt 2018 Printed Companion (pp. 53-61). ETC Press. 
Vanek, A., \& Peterson, A. (2016). Live Action Role-Playing (LARP): Insight into an Underutilized Educational Tool. In K. Schrier (Ed.), Learning and Education Games: Volume Two (pp. 219-240). Pittsburgh, PA: ETC Press.

Webb, M. (2018). Why Your LARP's Safety System Will Fail: A Hacker's Guide to Engineering Player Safety. Retrieved from The Fool Reversed website: <http://www.foolreversed.com/why-your-larps-safety-system-will-fail-a-hackers-guide-to-engineering-player-safety/>.

Zagal, J. P., \& Deterding, S. (2018). Definitions of "Role-Playing Games." In J. P. Zagal \& S. Deterding (Eds.), Role-Playing Game Studies: Transmedia Foundations. New York: Routledge.

All sources were last accessed on 16 December 2020.

\begin{abstract}
Michat Mochocki, PhD - works as assistant professor at Kazimierz Wielki University in Bydgoszcz. His main research interests are non-digital role-playing games, especially those set in historical storyworlds. His forthcoming book Role-play as a Heritage Practice (2021, Routledge) investigates historical role-playing through the lenses of transmedia narratology and heritage studies
\end{abstract}

\title{
Retoryki i mechaniki bezpieczeństwa graczy w nordycko- amerykańskim dyskursie larpowym
}

\begin{abstract}
Abstrakt: Artykuł opisuje ewolucję bezpieczeństwa larpowego w nordycko-amerykańskiej społeczności larpowej w ostatniej dekadzie. Zwraca uwagę na korelację między retoryką bezpieczeństwa (opiniami, debatami, politykami) a mechaniką (formalnymi zasadami regulującymi interakcje). Analiza wskazuje, że mniej więcej do 2010 roku powszechnie akceptowano istnienie ryzyka, a znaczna część odpowiedzialności za identyfikację zagrożeń i zapobieganie im spoczywała na graczu. Korelowało to z mechaniką słów bezpieczeństwa, którymi zestresowany gracz miał sygnalizować poziom dyskomfortu. Środkami bezpieczeństwa wymaganymi po stronie organizatorów były głównie bezpieczne pokoje off-game oraz interwencje i wsparcie emocjonalne w przypadkach przykrych przeżyć. Około 2014 roku debata o bezpieczeństwie przesunęła większą odpowiedzialność na graczy inicjujących potencjalnie przykre interakcje. Wiązało się to z wprowadzeniem mechaniki „ok-check", która wymaga komunikacji między inicjatorem i celem takiej interakcji. Około 2016 roku zapanował pogląd, że organizatorzy i uczestnicy powinni dołożyć wszelkich starań, by jakimkolwiek
\end{abstract}


przykrościom zapobiec. To znajduje swój wyraz w szybko rosnącym repertuarze mechanik kalibracji i przyzwolenia, które wyraźnie przenoszą odpowiedzialność za przekroczenie czyichś granic na tego, kto je przekroczyt. Mówiąc w uproszczeniu, pierwsze podejście każe graczom i organizatorom zatroszczyć się o osoby, które sygnalizują taką potrzebę. Drugie podejście nakazuje ostrożność przy testowaniu cudzych granic. Ostatnie zakłada, że granice należy ostrożnie rozpoznać i uszanować - nie testować.

Stowa kluczowe: larp, teatralna gra fabularna, role-playing, bezpieczeństwo, mechanika gry 